\title{
PREZYDENCJA REPUBLIKI CZESKIEJ W PIERWSZYM PÓŁROCZU 2009 ROKU JAKO PRZYKLAD SKUTECZNEGO ZARZĄDZANIA UNIĄ EUROPEJSKĄ
}

\begin{abstract}
Streszczenie. W artykule przedstawiono zalety i wady czeskiej prezydencji w Radzie Unii Europejskiej (styczeń-czerwiec 2009 r.). Prezydencja czeska była jedną z najciekawszych prezydencji ostatnich lat. Republika Czeska była dopiero drugą (po Słowenii) prezydencją państwa z grupy krajów, które przystąpiły do Unii Europejskiej podczas ,,wielkiego rozszerzenia” w 2004 roku. Prezydencja czeska rozpoczęła w bardzo trudnym dla Unii czasie (tj. głębokiego kryzysu gospodarczego w większości państw członkowskich UE, konfliktu gazowego między Rosją i Ukrainą, wojny w Gruzji, wyborów prezydenckich w USA, braku ratyfikacji traktatu lizbońskiego). Co więcej, w Republice Czeskiej panowała bardzo skomplikowana wewnętrzna sytuacja polityczna, w tym dymisja czeskiego rządu w połowie czeskiej prezydencji UE i eurosceptycyzm prezydenta Klausa. Jednak prezydencja czeska zasługuje na pozytywną ocenę. Z punktu widzenia administracji prezydencja była bardzo dobrze przygotowana, choć w momencie obalenia rządu w czasie prezydencji czeska klasa polityczna poniosła porażkę. Republika Czeska okazała się państwem członkowskim Unii Europejskiej, które dostrzega nowe wyzwania stojące przed UE i rozumie jej filozofię i mechanizmy. Czesi przyjęli perspektywę unijną i wykazali znacznie większe zrozumienie dla wspólnych ideałów niż państwa członkowskie o znacznie dłuższym członkostwie i znaczącej pozycji politycznej.

Słowa kluczowe: Republika Czeska, prezydencja w Radzie Unii Europejskiej, zarządzanie Unią Europejską, prezydencja Republiki Czeskiej.
\end{abstract}

\section{WPROWADZENIE}

Republika Czeska sprawowała prezydencję składów Rady Unii Europejskiej w okresie od 1 stycznia do 30 czerwca 2009 roku jako drugie po Słowenii z tzw. „nowych” państw członkowskich po wielkim rozszerzeniu Unii Europejskiej w 2004 roku. Celem tego opracowania nie jest szczegółowe odtwarzanie przebiegu tego przewodnictwa ${ }^{1}$, lecz uzasadnienie tezy, że Czesi, mimo pewnych widocznych niedociągnięć, byli, co do zasady, skuteczni w zarządzaniu Unią Europejską w dość jednak trudnym czasie dużych wyzwań. Już na początku przewodnictwa podważano zdolności organizacyjne Republiki Czeskiej. Nawet niektórzy czescy

* Uniwersytet Mikołaja Kopernika w Toruniu, Wydział Prawa i Administracji, Katedra Prawa Europejskiego,kwch@umk.pl.

${ }^{1}$ Przebieg i ocena zob. Czyżniewski, Witkowska-Chrzczonowicz (2011). 
analitycy i eksperci otwarcie wyrażali swoje wątpliwości, co do tego, czy Republika Czeska podoła wyzwaniom, jakie stawia przed nią przewodnictwo. „To mniej więcej tak, jakby autobusem z 27 pasażerami miał nagle pokierować nastolatek, który ledwo dostał prawo jazdy. Poprzedni, Słowenia, był dobrze ułożony, a droga pusta. Teraz za kierownicą siada rozbrykany nastolatek, na dodatek droga jest tłoczna, a przed nami wielkie skrzyżowanie. Trudno się dziwić, że reszta pasażerów się niepokoi"- powiedział publicznie Jiří Pehe, komentator polityczny i były doradca prezydenta Havla (Smoczyński 2008, 80).

\section{SUKCESY CZESKIEJ PREZYDENCJI}

Czesi z ogromnym wyczuciem określili priorytety prezydencji. Dodajmy, że robi się to $\mathrm{z}$ dużym wyprzedzeniem czasowym, więc nierzadko trudno jest precyzyjnie z nimi „trafić". Republika Czeska, kształtując swoje priorytety 3 x „E” (Ekonomia. Energetyka. Europa w świecie) przyjęła słuszne wówczas założenie koncentracji na sprawach gospodarczych oraz wzmacniania i kształtowania pozycji UE jako podmiotu stosunków międzynarodowych. Zresztą i kryzys gazowy, i finansowy, i sytuacja na Bliskim Wschodzie podczas prezydencji czeskiej potwierdziły słuszność rozłożonych akcentów.

Doświadczenia czeskiego przewodnictwa pokazały też po raz kolejny siłę medialnego wizerunku. Prezydencja wprawdzie nie umiała „sprzedać” medialnie takich merytorycznych sukcesów jak np. uruchomienie Partnerstwa Wschodniego, a media starały się eksponować porażki przewodnictwa, jednakże czeskiej prezydencji udało się znakomicie nagłośnić nieformalny szczyt Unia Europejska - USA zorganizowany w Pradze w dniu 5 kwietnia 2009 roku, na który przybyli przywódcy państw UE i wówczas nowy prezydent USA, Barak Obama. W 2010 roku tak dobrze wypromowana podczas prezydencji Praga gościła po raz kolejny ówczesnego prezydenta USA Obamę oraz ówczesnego prezydenta Rosji, Dymitrija Miedwiediewa, którzy 8 kwietnia 2010 roku podpisali tam traktat o ograniczeniu broni jądrowej START. Prezydencja była i jest wymarzoną okazją do wypromowania stolicy, a zwłaszcza tak pięknej stolicy, jaką jest Praga.

Czesi bardzo dobrze i z dużym zaangażowaniem wywiązywali się z zadania, jakie związane jest z funkcją administrowania działaniami Rady tam, gdzie należało uruchomić zdolności organizacyjne. Spotkania międzynarodowe na różnych szczeblach były bardzo dobrze przygotowywane, odpowiednio wcześnie docierały do ich uczestników wszystkie potrzebne materiały, a dziennikarze mieli dostęp do informacji oraz wręcz perfekcyjnie zorganizowanego zaplecza technicznego. Prezydencja czeska zawczasu przygotowała specjalne centrum konferencyjne w Pradze, które zostało usytuowane tak, by zapewnić jak najlepsze możliwości 
poruszania się między tym centrum a lotniskiem oraz gwarantowało uczestnikom spotkań odpowiednie i bardzo nowoczesne zaplecze.

Ważnym elementem każdego przewodnictwa jest również współpraca prezydencji z tzw. sektorem trzecim. Warto z nim chociażby konsultować obrane priorytety przewodnictwa i dzielić obowiązki informowania społeczeństwa o tym, czym jest przewodnictwo, jakie są jego cele i funkcje. Chodzi o to, by wykorzystać wiedzę i doświadczenie ekspertów także spoza sfery rządowej i zbudować sieć nieformalnych, opartych na zaufaniu kontaktów między administracją odpowiedzialną za przygotowanie przewodnictwa a przedstawicielami rozmaitych podmiotów i organizacji o charakterze pozarządowym (Lada, Partnerstwo..., 31-35). Tutaj Czesi poradzili sobie bardzo dobrze.

Wobec mniejszych i tzw. „nowych” państw UE sprawujących prezydencję większe państwa czasami pozwalają sobie na ostrzejszą krytykę. Ówczesny Prezydent Francji, Nicolas Sarkozy w swoim oficjalnym wystąpieniu przed Parlamentem Europejskim, przed zakończeniem przewodnictwa Francji w Radzie UE 16 grudnia 2008 roku, skrytykował, a wręcz zbeształ czeskie przygotowania do objęcia przewodnictwa w UE, ponieważ... na wszystkich budynkach państwowych nie powiewała flaga $\mathrm{UE}^{2}$. Powszechnie wiadomo, że ówczesny prezydent Republiki Czeskiej, Vaclav Klaus nie wyrażał zgody na powieszenie flagi UE w swojej siedzibie na Zamku Praskim. Można było podzielać jego eurosceptycyzm albo go nie podzielać, ponieważ na tym polega demokracja, że jest w niej miejsce na różne poglądy, ale taka krytyka stanowiła nie tylko mało elegancką formę, ale wręcz niedopuszczalną ingerencję w sprawy wewnętrzne innego państwa. Należy się zastanowić, czy prezydent Francji mówiłby tak samo, gdyby raził go brak flag UE na budynkach rządowych innych, większych państw UE, w przededniu objęcia przez takie kraje prezydencji. Ówczesny czeski minister spraw zagranicznych, Karel Schwarzenberg znakomicie odpowiedział na zarzuty Sarkozy’ego, oświadczając że „,nawet gdyby większość mieszkańców UE i przedstawicieli państw członkowskich zażyczyła sobie, by flaga UE zawisła na Hradczanach, to tylko od Prezydenta Republiki zależy, czy tak się stanie, a obowiązku jej wywieszenia nie określa w Republice Czeskiej żaden przepis obowiązującego prawa. Nie przystoi głowie innego państwa krytykować z tego powodu naszego Prezydenta"3 i udowadniając, że małe państwa członkowskie powinny umieć być asertywne.

Widać więc, że państwa „starej UE” czasami udowadniają, że „nowym” wolno mniej, że „nowi” muszą starać się bardziej niż inni. Przy czym oczywiście z formalnego punktu widzenia status Republiki Czeskiej jako państwa członkowskiego UE nie różni się, i nie różnił się, niczym od statusu Francji.

${ }^{2}$ Zob. http://zpravy.idnes.cz/tiskni.asp?zahranicni\&c=A081216_122559_zahranicni_stf [dostęp 3.03.2018].

${ }^{3}$ Tamże. 
Drugim incydentem było słynne spotkanie prezydenta Václava Klausa z posłami do Parlamentu Europejskiego, które odbyło się na Zamku Praskim 5 grudnia 2008 roku, tuż przed objęciem przewodnictwa przez Republikę Czeską i zakończyło się skandalem politycznym. Członkowie Konferencji Przewodniczących PE z różnych państw zaatakowali Prezydenta Republiki, m.in. zarzucając mu w trakcie oficjalnego spotkania niejasne powiązania ze znanym irlandzkim eurosceptykiem Declanem Ganleyem, czy brak wywieszenia flagi UE na Hradczanach. Daniel Cohn-Bendit (z frakcji Zieloni/EFA) stwierdził także, że prezydent „będzie musiał podpisać traktat lizboński”. Natomiast Brian Crowley z frakcji UEN powiedział, że poprzez spotkanie w Irlandii z Ganleyem Prezydent Republiki dopuścił się „obrazy irlandzkiego narodu”. Prezydent Klaus, znieważony w swojej siedzibie stwierdził, że w ten sposób i tym tonem nikt jeszcze z nim na Hradczanach nie rozmawiał przez sześć lat jego prezydentury, Cohn-Benditowi odpowiedział, że nie jest w Pradze na paryskich barykadach i że sądził, że taki styl komunikacji wobec Czechów skończył się 19 lat temu. Niezależnie od poglądów Václava Klausa, członkowie Parlamentu Europejskiego dopuścili się nieodpowiedniego zachowania. Tak zwane „nowe państwa” w UE to kraje, wobec których niektórzy partnerzy (duże państwa członkowskie czy silne instytucje UE) mogą próbować grać „ostrzej”. Trzeba zatem, jeśli takie ciosy padną, trafnie i asertywnie na nie reagować, ponieważ stawką jest nie tylko sukces prezydencji, ale przede wszystkim budowanie pozycji państwa w UE. To się bardzo dobrze Czechom udawało podczas prezydencji.

Wydaje się, że za największy sukces czeskiej prezydencji (zwłaszcza z punktu widzenia Europy Środkowo-Wschodniej) można uznać działania związane z uruchomieniem programu Partnerstwa Wschodniego. Był to celnie dobrany priorytet (zwłaszcza w obliczu kryzysu finansowego i idącej za nim niestabilnej sytuacji w państwach objętych tym programem, jak np. Ukraina), a Republika Czeska zaangażowała wszelkie dostępne środki dla rozpoczęcia tego programu. Wydaje się, że każde państwo członkowskie, a zwłaszcza położone na Wschodzie Europy powinno $\mathrm{w}$ ramach swoich priorytetów jak najskrupulatniej promować i kontynuować Partnerstwo Wschodnie. Wobec instytucji UE czeskie przewodnictwo starało się wypaść bardzo dobrze i dbać o skuteczną współpracę.

Wydaje się, że dość dobrze układała się współpraca czeskiej prezydencji z Komisją Europejską, która wspierała przewodnictwo m.in. w walce z wprowadzaniem protekcjonizmu w gospodarce, ale także zdarzało się jej przejmować inicjatywę, kiedy przewodnictwo reagowało zbyt wolno lub z jakichś przyczyn nie potrafiło zdobyć się na bardziej zdecydowane reakcje w rozmaitych sprawach, zwłaszcza istotnej wagi międzynarodowej.

Jeśli chodzi o relacje z Parlamentem Europejskim, to były one jednak dość napięte, na co złożyło się kilka czynników. Były to m.in. niefortunna rozmowa posłów do PE z prezydentem Klausem na Hradczanach tuż przed przejęciem prezydencji przez Republikę Czeską, rzucający się wówczas bardzo w oczy brak 
ratyfikacji traktatu z Lizbony, na co szczególnie zwracał uwagę Parlament Europejski oraz słynne już kontrowersyjne przemówienie prezydenta Václava Klausa, wygłoszone 19 lutego 2009 roku podczas posiedzenia plenarnego PE ${ }^{4}$. Prezydent Klaus, któremu jako głowie państwa sprawującego przewodnictwo w UE przysługuje prawo do wygłoszenia przemówienia w $\mathrm{PE}$, nie podlegającego jednak potem debacie, w swoim wystąpieniu wprawdzie stwierdził, że nie ma dla Republiki Czeskiej innej alternatywy niż członkostwo w UE, ale kolejne jego słowa spowodowały wręcz konsternację. Zakwestionował on kierunki pogłębienia integracji w ramach UE oraz zarzucił, że unijne procedury nie są demokratyczne. Wskazywał także na brak dyskusji w samej UE i w PE, w którym nie ma miejsca dla opozycji, co zestawił z systemem komunistycznym, w którym nie było opozycji i nie było wolności. Porównanie systemu UE do komunizmu, a systemu wspólnego rynku do modelu gospodarki centralnie planowanej tak bardzo rozzłościło część posłów, że ostentacyjnie opuścili oni salę obrad w trakcie przemówienia Klausa (Słojewska, Vaclav Klaus...). Wystąpienie zostało przyjęte entuzjastycznie tylko przez nielicznych eurosceptyków z grupy Niepodległość i Demokracja. Kontrowersyjny lider grupy, Nigel Farage, stwierdził po wystąpieniu Václava Klausa, że dokonał on „niszczycielskiego dzieła”. „Porównanie klasy rządzącej w UE do elit komunistycznych to chyba najostrzejsze słowa, jakie usłyszałem w Parlamencie Europejskim" - stwierdził Farage (Słojewska, Vaclav Klaus...).

Z kolei wystąpienie premiera Mirka Topolánka, który przemawiał w PE 14 stycznia 2009 roku, a więc zaraz po rozpoczęciu czeskiego przewodnictwa, nie zawierało kontrowersyjnych tez i polegało na zaprezentowaniu priorytetów i oczekiwań, że UE i PE będą wspierać przewodnictwo w tym tak trudnym okresie 5 .

Wyżej omówiono silne strony czeskiego przewodnictwa. Tym niemniej, by być obiektywnym, należy także trochę wspomnieć o błędach i niedociągnięciach czeskiej prezydencji.

\section{NIEDOCIĄGNIĘCIA I PORAŻKI CZESKIEJ PREZYDENCJI}

Współpraca Republiki Czeskiej w ramach prezydencji z Francją nie układała się zupełnie, i to z winy obu stron. Ówczesny prezydent Vacláv Klaus afiszował się ze swoim eurosceptycyzmem. A ówczesny prezydent Francji, Nicolas Sarkozy nieustannie, napastliwie krytykował czeskie przewodnictwo, podważał jego działania, a nawet uzurpował sobie prawo do jego zastępowania (jak chociażby w sytuacji, kiedy na Bliski Wschód pojechały dwie delegacje: oficjalna, unijna, czeska i nieoficjalna, konkurencyjna, francuska). Takie podejmowane przez Francję

${ }^{4}$ Całe przemówienie prezydenta Klausa jest dostępne w Internecie na stronie http://www.youtube.com/watch?v=_XjD9ApJi0Y [dostęp 7.03.2018].

5 Zob. http://www.europarl.europa.eu/news/expert/infopress_page/004-46092-012-01-03-90120090113IPR46091-12-01-2009-2009-false/default_pl.htm [dostęp 7.03.2018]. 
działania były oczywiście niedopuszczalne, ale... Skuteczną politykę w UE przy obiektywnie mniej znaczącej pozycji niż pozycja innych państw w Unii, można prowadzić tylko wówczas, gdy dla swoich pomysłów, projektów i sposobów ich realizacji znajdzie się wsparcie wśród najbardziej wpływowych partnerów. Dziś takimi partnerami w UE są bezdyskusyjnie Niemcy i Francja, a po Brexicie ich pozycja jeszcze się wzmocni. Wejście w otwarty spór polityczny z którymkolwiek $\mathrm{z}$ tych państw $\mathrm{w}$ przededniu lub $\mathrm{w}$ trakcie sprawowania przewodnictwa przez mniejszy kraj Unii Europejskiej, dodatkowo jeszcze od niedawna funkcjonujący w jej strukturach, świadczy o braku realizmu w polityce europejskiej. Nowe państwo UE, obejmujące przewodnictwo powinno jeszcze przed jego przejęciem prowadzić wysiłki dyplomatyczne dla znalezienia poparcia dla swych inicjatyw, priorytetów i sposobów ich realizacji przede wszystkim w dużych, najbardziej znaczących państwach UE.

Kilka mało znaczących politycznie, ale chwytliwych medialnie wydarzeń z okresu czeskiej prezydencji przebiło się do świadomości Europejczyków. Gazety rozpisywały się o skandalu, jaki wywołała instalacja Davida Černego, czeskiego rzeźbiarza, który w Brukseli w sposób kontrowersyjny i stereotypowy (a nawet obraźliwy dla niektórych krajów, jak to było w przypadku Bułgarii) przedstawił poszczególne państwa UE. Czesi, znani ze swoich liberalnych poglądów na sztukę, w większości nie widzieli nic szczególnie kontrowersyjnego w tej instalacji, ale w Europie zawrzało do tego stopnia, że Bułgaria - przedstawiona jako turecka toaleta - zażądała zasłonięcia obrażającego ją fragmentu instalacji. Przy promocji przewodnictwa zatem najlepiej postawić na sprawdzonych, odnoszących międzynarodowe sukcesy artystów, czy na popularyzację już dobrze wypromowanego i obecnego w umysłach Europejczyków dorobku kulturalnego i artystycznego danego państwa. Promocja prezydencji to nie czas na eksperymenty, ale raczej na zaangażowanie sprawdzonych pomysłów i artystów, znanych szerszej europejskiej publiczności, kojarzonych $\mathrm{z}$ danym państwem i darzonych powszechnym szacunkiem. W okresie czeskiej prezydencji odbyło się ponad 600 wydarzeń kulturalnych, a z powodu skandalu najlepiej zapamiętano niefortunną instalację Černego! W pamięci utrwaliło się również przywołane wcześniej wystąpienie prezydenta Republiki Czeskiej Václava Klausa w Parlamencie Europejskim. Tego typu wydarzenia nie mają większego praktycznego wpływu na przebieg i skuteczność prezydencji, ale są nośne medialnie. Stąd unikanie nieprzemyślanych posunięć, nawet z pozoru nic nie znaczących jest kluczowe dla sukcesu przewodnictwa.

Prezydencja czeska była sprawowana w okresie dynamicznych zmian w samej UE i w czasie trudnym, jeśli chodzi o sytuację międzynarodową - nałożyły się na siebie kryzys finansowy, konflikt izraelsko-palestyński w Strefie Gazy, rosyjsko-ukraiński kryzys gazowy, trudności z ratyfikacją traktatu z Lizbony - żeby wspomnieć tylko te najbardziej spektakularne. Chociaż - nazwijmy to - „bieżące" zarządzanie Unią Europejską rzeczywiście wychodziło czeskiej prezydencji dobrze i skutecznie, to na niektóre z tych nieprzewidzianych wydarzeń Czesi 
niestety nie byli przygotowani. Prezydencja generuje ogromną odpowiedzialność za funkcjonowanie Unii Europejskiej i żadne (małe czy duże) państwo UE nie może lekkomyślnie wychodzić z założenia o skoncentrowaniu się jedynie na dobrym przygotowaniu priorytetów, a więc z założenia, że nic nieprzewidzianego, co będzie wymagało reakcji prezydencji się nie zdarzy. Zawsze jednak mogą wystąpić niespodziewane okoliczności (a czeska prezydencja jest tego dobitnym przykładem), na które trzeba będzie reagować na bieżąco, przy czym reakcja będzie musiała być współmierna do tych okoliczności, zdecydowana i przemyślana, a jednocześnie zwykle szybka. Musi wręcz ona przybrać dosłownie formę „zarządzania kryzysowego". W kwestiach energetycznych istotnym i nieprzewidzianym wydarzeniem okazał się rosyjsko-ukraiński konflikt gazowy. Przewodnictwo czeskie zareagowało zbyt późno, ale potem trafnie postawiło na koncepcję zaangażowania UE w znalezienie wyjścia z sytuacji. Najpierw traktowało spór jako dwustronne zagadnienie handlowe, a kiedy okazało się, że ma ono swoje implikacje w państwach UE i niektóre z nich wyraźnie odczuwają zmniejszenie dostaw gazu, przewodnictwo podjęło bardziej zdecydowane kroki, polegające m.in. na zwołaniu nieformalnego posiedzenia Rady ds. Energii, przekonaniu stron sporu o konieczności zaangażowania UE w rozwiązanie konfliktu, a następnie przyjęciu neutralnej postawy wobec obu stron i przyjęciu roli mediatora $\mathrm{w}$ żmudnych negocjacjach.

Czesi zupełnie nie poradzili sobie $\mathrm{z}$ zagwarantowaniem wewnętrznej stabilności sceny politycznej. Nie potrafili ani na etapie przygotowań do przewodnictwa, ani w czasie jego trwania zawrzeć minimum kompromisu politycznego dla pokazania się w Unii Europejskiej od jak najlepszej strony, i to był czeski najcięższy „grzech”. Narastający konflikt między prezydentem Republiki a premierem Topolánkiem, podchwycony przez opozycję, okazał się politycznie tragiczny w skutkach dla czeskiej prezydencji. Po obaleniu czeskiego rządu pojawiające się w prasie nagłówki i tytuły artykułów, jak np. „Topolanek upadł, Unia bez głowy" dobitnie wskazywały na powagę sytuacji i odbiór takich decyzji. Do upadku rządu Topolánka doszło w najgorszym momencie. Wprawdzie od samego początku po czeskiej prezydencji nie spodziewano się wiele, ale premier Topolánek stopniowo zdobywał zaufanie, ponieważ zażegnał konflikt gazowy między Rosją a Ukrainą, spowodował ogólnoeuropejską dyskusję o protekcjonizmie, kiedy ostro odpowiedział Sarkozy'emu na oświadczenie o przenoszeniu produkcji samochodowej z Czech za granicę, całkiem dobrze poradził sobie na marcowym szczycie Rady Europejskiej ${ }^{7}$ Tymczasem, mimo że czeski rząd „złapał wiatr w żagle” i miał widoki na dobrą drugą połowę prezydencji, Czesi „strzelili sobie samobója"8. Obalenie rządu w trakcie przewodnictwa był to, zdaniem

\footnotetext{
${ }^{6}$ Zob. „Topolanek upadł, Unia bez głowy”, Gazeta Wyborcza $\mathrm{nr} 71$ z 25.03.2009, s. 1.

${ }^{7}$ Por. P.M. Kaczyński, wypowiedź na łamach Gazety Wyborczej nr 71 z 25.03.2009, s. 7.

${ }^{8}$ Tamże.
} 
Jeana Quatremera, korespondenta francuskiego dziennika „Liberation”, „dowód całkowitego prowincjonalizmu" ". Wydaje się nawet, że sama opozycja przestraszyła się tego, co się stało już po fakcie, ponieważ szef socjaldemokratów, czyli największej partii opozycyjnej, Jiří Paroubek, który w trakcie debaty stwierdził, że rząd Topolánka jest „eurohaniebny”, po ogłoszeniu wyników głosowania nad wotum nieufności zaproponował, by jednak dokończył on prezydencję, a więc działał do końca czerwca (Palata 2009a, 7). Skutkiem zamieszania politycznego w Republice Czeskiej było to, że Unia z dnia na dzień zaczęła bardziej ignorować czeską prezydencję, a na szczyt dotyczący Partnerstwa Wschodniego, który odbył się 7 maja 2009 roku w Pradze z przywódców największych państw UE przyjechała jedynie kanclerz RFN, Angela Merkel (Palata 2009b, 6). Niestety czeskie przewodnictwo jest, i pewnie będzie, oceniane bardzo krytycznie tylko poprzez pryzmat wotum nieufności wobec rządu Topolánka i jego upadek. Taka ocena jest krzywdząca, bo jest jedynie fragmentaryczna, ale niestety to ona ,przebiła się” do mediów i zakorzeniła się w świadomości Europejczyków. Potwierdza ona jeszcze raz wagę tego, co nazywamy wizerunkiem medialnym i stanowić powinna istotną przestrogę dla innych państw członkowskich.

\section{KONKLUZJE}

Czesi niewątpliwie podczas swojej prezydencji osiągnęli pewne sukcesy, jak np. uruchomienie Partnerstwa Wschodniego czy organizacja szczytu Unia Europejska - USA w Pradze. Nie umieli jednak w sposób wystarczający tych sukcesów nagłośnić i wyeksponować. Promocja prezydencji też pozostawiała wiele do życzenia. W samej Republice Czeskiej prezydencji poświęcono sporo uwagi, choć kampania promocyjna Evropě to osladíme! (Posłodzimy Europę!) ze słynną kostką cukru nie była najlepszym pomysłem i wielu Czechów deklarowało, że jej nie rozumie, inni zaś doszukiwali się w niej ukrytego sensu, ponieważ w języku czeskim ,posłodzenie komuś” oznacza mniej więcej to samo, co w języku polskim ,przysolenie komuś” i ma pejoratywny wydźwięk. Zatem kampania promocyjna prezydencji była stosunkowo słaba, natomiast sama prezydencja była dobrą i - jak się okazało - wykorzystaną sposobnością do wypromowania Pragi.

Czesi w trakcie prezydencji musieli zmierzyć się z bardzo trudną sytuacją i w samej UE, i na świecie. Republika Czeska była także w tym czasie pogrążona w wewnętrznym konflikcie politycznym.

Dopóki rząd Topolánka nie został obalony, prezydencja ze zmiennym szczęściem radziła sobie z rozmaitymi nieprzewidzianymi trudnościami, jak np. rosyjsko-ukraiński konflikt gazowy. Upadek rządu Topolánka sprawił, że politycznie Europa przestała się z nim liczyć.

\footnotetext{
${ }^{9}$ Por. Jean Quatremer, wypowiedź, tamże.
} 
Czeska administracja wykonała solidną pracę i ze swoich zadań w okresie prezydencji, do których pełnienia przygotowywała się rzetelnie przez kilka lat, wywiązała się bardzo dobrze. Niestety, za odpowiedzialną postawą urzędników, nie poszła dojrzałość czeskiej klasy politycznej. Politycy w sposób nieodpowiedzialny wciągnęli Unię Europejską w ostry, wewnętrzny spór polityczny, co całkowicie zrujnowało wizerunek prezydencji i jest do dziś przyczyną bardzo krytycznych jej ocen. Czescy politycy przedłożyli niezrozumiałe dla większości Europejczyków wewnątrzpartyjne spory ponad interes państwa w UE, a nawet interes całej Unii, która w tak trudnym momencie kryzysu finansowego potrzebowała silnego przywództwa. Przywództwa, jakiego Republika Czeska nie mogła zaoferować. Politycy, zamiast wzorem Słowenii, która sprawowała przewodnictwo w UE w pierwszej połowie 2008 roku, przyjąć „rozejm polityczny” na czas prezydencji, w sposób nieodpowiedzialny wciągnęli Unię Europejską w ostry, wewnętrzny spór polityczny, który zaowocował kryzysem i wreszcie obaleniem rządu Topolánka.

Jednak prezydencja osiągała stopniowo wyznaczone cele, jak uruchomienie Partnerstwa Wschodniego, czy zaawansowanie procesu ratyfikacji traktatu z Lizbony w Republice Czeskiej, na co inni partnerzy europejscy bardzo czekali. Udało się przyjąć wiele ważnych aktów prawnych i uzgodnić istotne plany oraz projekty (jak chociażby plan walki z kryzysem finansowym opiewający na 5 mld euro).

Czeskie przewodnictwo należy oceniać całościowo umiarkowanie pozytywnie $\mathrm{w}$ tym sensie, że osiągnęło ono wyznaczone cele i w danych okolicznościach wykonało maksimum tego, co było możliwe do uzyskania. Obraz prezydencji zniszczył jednak wizerunek medialny, upadek rządu i kontrowersyjne, podchwycone przez media sytuacje.

Najistotniejszą lekcją dla wszystkich polityków, których państwa kiedykolwiek staną wobec perspektywy przejęcia przewodnictwa w Unii Europejskiej powinno być obalenie czeskiego rządu w trakcie prezydencji i opłakane skutki tego nieodpowiedzialnego posunięcia. Zapewnienie stabilności sytuacji politycznej w obliczu odpowiedzialności jaką niesie ze sobą sprawowanie prezydencji powinno być zawsze nadrzędnym celem każdego rządu i każdej opozycji.

\section{BIBLIOGRAFIA}

Czyżniewski, Marcin, Witkowska-Chrzczonowicz, Katarzyna. 2011. Prezydencja Republiki Czeskiej w Radzie Unii Europejskiej. Studium prawno-politologiczne. Warszawa: Wydawnictwo Sejmowe.

Łada, Agnieszka. Partnerstwo dla Prezydencji? Wspótpraca administracji z sektorem pozarzadowym podczas czeskiej Prezydencji w Radzie Unii Europejskiej - wnioski dla Polski. Raport z badań Instytutu Spraw Publicznych dostępny na stronach internetowych Instytutu Spraw Publicznych, http://www.isp.org.pl/files/20174315650396766001260455529.pdf.

Palata, Lubosz. 2009a. „Topolanek padł w Pradze”. Gazeta Wyborcza 71. 
Palata, Lubosz. 2009b. „Czesi mają rząd, a Europa prezydencję”. Gazeta Wyborcza 108.

Słojewska, Anna. Vaclav Klaus: w Unii jak za komunizmu, http://www.rp.pl/artykul/36,265790_Vaclav_Klaus_w_Unii_jak_za_komunizmu.html.

Smoczyński, Wawrzyniec. $200 \overline{8}$. „Po kostki w Unii”. Polityka 50 (2684): 78-80.

http://www.europarl.europa.eu/news/expert/infopress_page/004-46092-012-01-03-90120090113IPR46091-12-01-2009-2009-false/default_pl.htm.

http://zpravy.idnes.cz/tiskni.asp?zahranicni\&c=A081216_122559_zahranicni_stf.

www.archiwum.isp.org.pl.

Katarzyna Witkowska-Chrzczonowicz

\title{
THE PRESIDENCY OF THE CZECH REPUBLIC IN THE FIRST HALF OF 2009 AS AN EXAMPLE OF AN EFFECTIVE MANAGEMENT OF THE EUROPEAN UNION
}

\begin{abstract}
The paper hereby presented discusses the advantages and disadvantages of the Czech Presidency of the Council of the European Union (January - June 2009). The Czech Presidency was one of the most interesting presidencies in the recent years. The Czech Republic was only the second (after Slovenia) to hold the presidency form among the group of countries which joined the European Union during the "great enlargement" in 2004. The Czech presidency began in a very difficult time for the Union (i.e. a profound economic crisis in most Member States of the EU, the gas conflict between Russia and Ukraine, the war in Georgia, the presidential elections in the U.S, the lack of ratification of the Lisbon Treaty).

Moreover, there was a very complicated internal political situation in the Czech Republic including the dismissal of the Czech government in the Middle of the Czech EU Presidency and president Klaus's eurosceptical pronouncements.

However, the Czech Presidency deserves a positive assessment. From the administrative point of view, the Presidency was very well prepared, although at the moment of overturning the government during the presidency, the Czech political class did fail.

The Czech Republic proved to be an European Union Member State which recognizes new challenges facing the EU and understands its philosophies and mechanisms. Czechs adopted a EU perspective and demonstrated a much greater understanding for the common ideals than the Member States of much longer membership and more significant political position.
\end{abstract}

Keywords: The Czech Republic, Presidency of the Council of the European Union, Management of the European Union, The Presidency of the Czech Republic 